\title{
Regional labour market forecasts by education and occupation in the Netherlands
}

Citation for published version (APA):

Berendsen, H., de Grip, A., Wieling, M., \& Willems, E. J. T. A. (1992). Regional labour market forecasts by education and occupation in the Netherlands. Researchcentrum voor Onderwijs en Arbeidsmarkt, Faculteit der Economische Wetenschappen. ROA Research Memoranda No. 5E https://doi.org/10.26481/umaror.199205E

Document status and date:

Published: 01/01/1992

DOI:

10.26481/umaror.199205E

Document Version:

Publisher's PDF, also known as Version of record

\section{Please check the document version of this publication:}

- A submitted manuscript is the version of the article upon submission and before peer-review. There can be important differences between the submitted version and the official published version of record.

People interested in the research are advised to contact the author for the final version of the publication, or visit the DOI to the publisher's website.

- The final author version and the galley proof are versions of the publication after peer review.

- The final published version features the final layout of the paper including the volume, issue and page numbers.

Link to publication

\footnotetext{
General rights rights.

- You may freely distribute the URL identifying the publication in the public portal. please follow below link for the End User Agreement:

www.umlib.nl/taverne-license

Take down policy

If you believe that this document breaches copyright please contact us at:

repository@maastrichtuniversity.nl

providing details and we will investigate your claim.
}

Copyright and moral rights for the publications made accessible in the public portal are retained by the authors and/or other copyright owners and it is a condition of accessing publications that users recognise and abide by the legal requirements associated with these

- Users may download and print one copy of any publication from the public portal for the purpose of private study or research.

- You may not further distribute the material or use it for any profit-making activity or commercial gain

If the publication is distributed under the terms of Article $25 \mathrm{fa}$ of the Dutch Copyright Act, indicated by the "Taverne" license above, 


\section{REGIONAL LABOUR MARKET FORECASTS \\ BY EDUCATION AND OCCUPATION \\ IN THE NETHERLANDS}

ROA-RM-1992/5E

H. Berendsen, A. De Grip,

M.H. Wieling, E.J.T.A. Willems

RESEARCH CENTRE FOR EDUCATION AND THE LABOUR MARKET

Rijksuniversiteit Limburg

Faculty of Economics and Business Administration

Maastricht, October 1992 
Regional

Regional labour market forecasts by education and occupation in the Netherlands / $\mathrm{H}$. Berendsen... [et al.] - Maastricht: Research Centre for Education and the Labour Market, Rijksuniversiteit Limburg, Faculty of Economics and Business Administration. - (ROA-RM1992/5E)

Met lit. opg.

ISBN 90-5321-092-X in ringband

Trefw.: onderwijs en arbeidsmarkt; Nederland. 


\section{CONTENTS}

ABSTRACT

i

1. INTRODUCTION

2. EXPANSION DEMAND

3. REPLACEMENT DEMAND

4. JOB OPENINGS

5. INFLOW OF SCHOOL LEAVERS

6. CHARACTERIZATION OF THE FUTURE LABOUR MARKET SITUATION 


\section{ABSTRACT}

In this paper a methodology is developed for regional forecasts at a rather detailed level by both occupational class and type of education. Forecasts are made for the expansion demand, the replacement demand and the flow of school leavers onto the labour market. The confrontation of future labour demand and future labour supply leads to an indicator of the future labour market prospects for school leavers with a certain type of education at a regional level. All these forecasts are consistent with the national forecasts. The results show that usually small regional differences in the employment structure and the flow of school leavers onto the labour market can lead to significant differences in the expected situation on the labour market. 


\section{INTRODUCTION}

Even in a rather small country as the Netherlands the matching problems on the labour market are largely regional in nature. Probably apart from the higher skilled, labour supply merely focuses on the local or regional labour market. Employers also direct their recruitment efforts for lower and intermediately skilled workers mainly at the regional labour market. Moreover the recent reorganization of the Employment Services' Organization shifted the emphasis of public labour market policy towards the regional level by the creation of relatively independent Regional Employment Boards. Therefore, there is a very great need for region-specific labour market information, especially as regards General Secondary Education, Lower Vocational Education and Intermediate Vocational Education (De Grip, 1991).

In this paper a methodology will be developed which enables us to set up regional labour market forecasts by occupational class and type of education, on the basis of the available data ${ }^{1}$. In order to avoid regression analyses on regional data form the Dutch Labour Force Survey that due to the low level of aggregation will not be reliable, an attempt is made to regionalize the national labour market forecasts of the Research Centre for Education and the Labour Market (ROA). An advantage of this approach is also that the regional demand and supply forecasts are consistent with the national forecasts.

The regional forecasts refer to the twelve Dutch provinces. Thereby 93 occupational classes and 20 types of education are distinguished. No provincial forecasts will be made for Higher Vocational Education and Academic Education or for 'Intermediate Vocational Education, Police \& Defense Forces'. For those holding qualifications in this group there is in fact little or no question of regionally defined labour markets, therefore it is not meaningful and in fact also impossible to draw up reliable labour market forecasts for these educational categories. Moreover, forecasts are made only for occupational classes or types of education in which at least 5,000 persons in the province in question are involved. This restriction results partly from the limitations which the Netherlands Central Bureau for Statistics (NCBS) applies in publishing the data from the Labour Force Survey, and partly because this is seen as a minimum size for reliable regional labour market forecasts.

In drawing up the provincial labour market forecasts by occupation and education, the 'employment flow' approach, which has already been used at a national level (ROA, 1992), was chosen. Figure 1 gives an overview of the flows on the labour market. On the demand side of the labour market a distinction can be made between the expected expansion demand on the basis of the future changes in employment levels and the expected replacement demand as a result of retirement, occupational mobility, etc.. The expansion demand and replacement demand together give the expected number of job openings. On the supply side of the labour market we have distinguished between the expected inflow of school leavers and the supply of

1. For a detailed account (in Dutch) see Berendsen, De Grip, Wieling and Willems (1992). 
Figure 1. Flows on the labour market

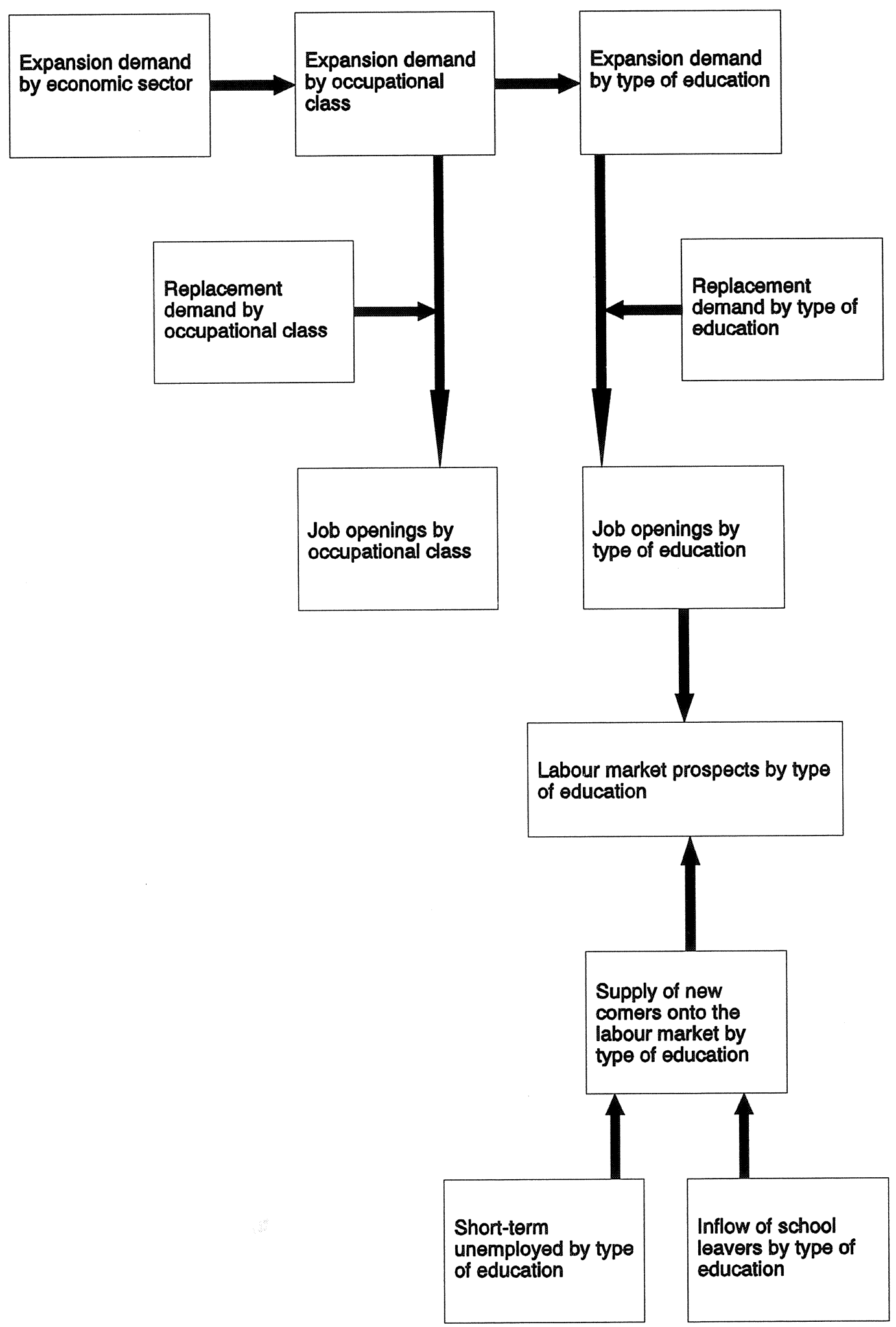


short term unemployed. By comparing the expected demand and supply flows to each other, an indication of the future labour market prospects for each type of education is gained. The forecasts relate to the period 1989-1994. It should be noted that the inter-regional mobility flows which may occur as a result of differences between the mismatches to be expected on the various regional labour markets are not included in the model. The forecasting results should therefore be interpreted as indications of regional differences to be expected in the labour market developments for each occupational class and type of education and the required education effort or inter-regional mobility necessary to restore the balance on the regional labour market. Although this paper deals with both the methodology and the results of our forecasts the final results of the forecasts are to spacious to present in detail, we selected five occupational classes and four types of education to illustrate the results of the various forecasts.

The structure of the remainder of this paper is as follows. First, in section 2, the expansion demand is discussed. Section 3 considers the replacement demand. These two sections explain the methodology used as well as giving the results for the selected occupational classes and types of education. Section 4 discusses the expected numbers of job openings. In section 5 the flow of school leavers from each type of education is presented, including also the methodology used and some of the results. Demand and supply are confronted in section 6 . Finally in section 7 some concluding remarks will be made. 


\section{EXPANSION DEMAND}

\section{Methodology}

This section examines the forecasts of the employment changes by province for each occupational class and each type of education in the period 1989-1994. Because of the limited reliability of any analysis on the basis of the available provincial data it was decided not to estimate province-specific models for the occupational and educational structure of employment. Instead the expected changes in the occupational and educational structure of employment at the national level are projected onto the existing and expected provincial industrial structure of employment ${ }^{2}$. This means that existing forecasts of provincial employment for each economic subsector are combined with national employment forecasts for each occupational class and type of education.

In figure 2 this approach has been presented schematically. Boxes of various shapes have been used. The data relating to the results or interim results from national forecasts is marked by a rectangle with rounded corners. The additional data required for the regional expansion demand model has been designated by a hexagon. The results or interim results of the regional model have been indicated by means of a rectangle. The two shaded rectangles represent the final forecasting results of the changes in provincial employment for each occupational class and type of education.

In the upper half of the diagram the 'regional occupational model' is presented. The first step relates to changes in the provincial employment in each economic subsector in the period 19891994. The second step shows the changes in national employment levels for each occupational class within the various subsectors of industry. By combining these two steps a forecast of employment for each occupational class in each province is obtained ${ }^{3}$. The bottom part of the diagram presents the 'regional educational model'. In it the results of the regional occupational model are combined with national changes in the educational structure within the occupational classes.

2. A similar approach is followed with regard to regional occupational forecasts in the United Kingdom (Lindley and Wilson, 1991).

3. Thus the approach used here differs from, for instance, the fixed coefficients methods that was used in the Canadian COFOR82 model (Foot, 1980). In that model, in contrast to our study, no account was taken of changes in the occupational structure within economic sectors. 
Figure 2. Methodology of the regional expansion demand

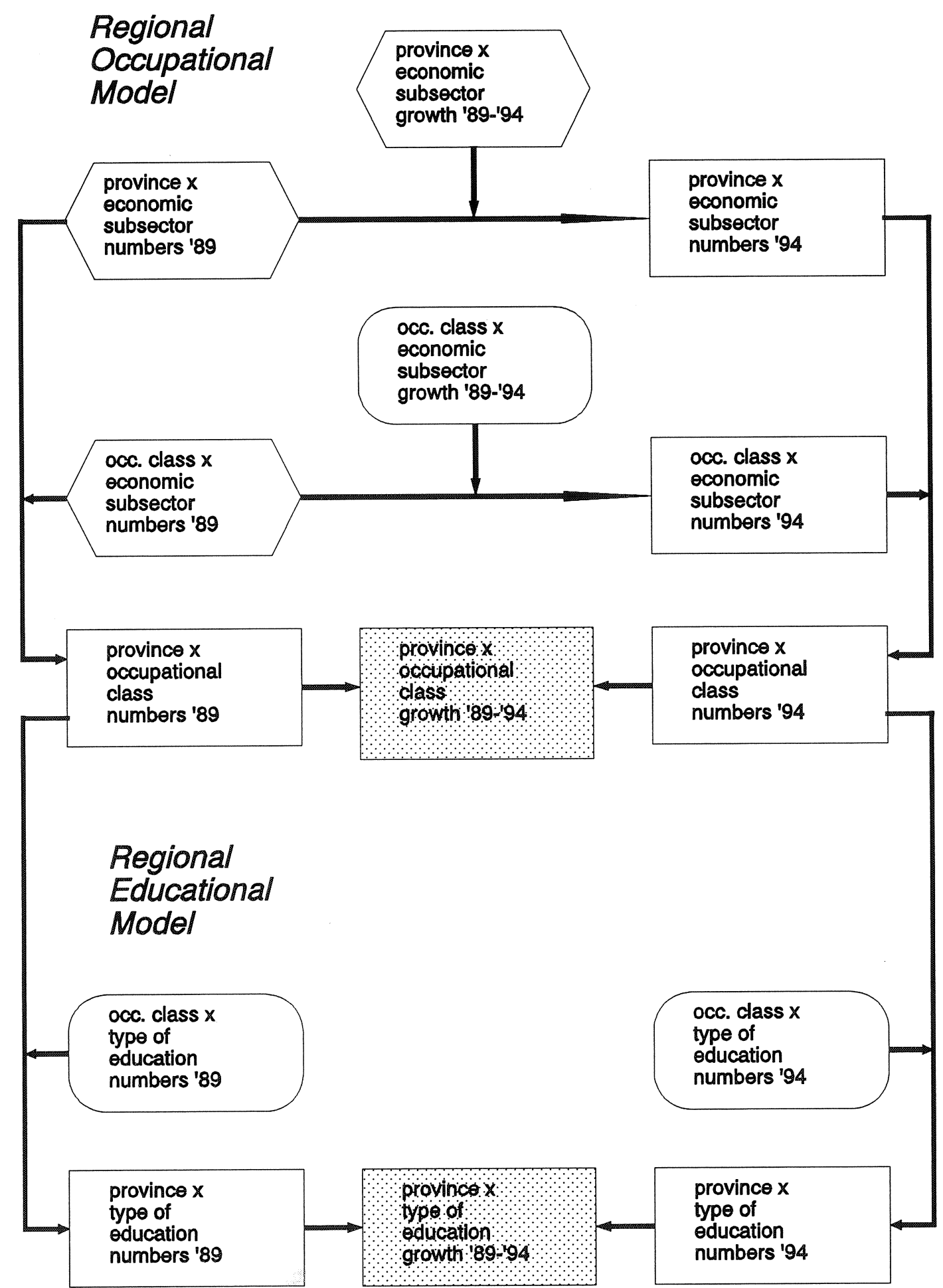


As has been indicated above, the first step in the regional occupational model relates to the provincial employment levels for each economic subsector. These are based on forecasts of changes in provincial employment for 13 economic sectors which are drawn up by the Employment Services (Natzijl and Westra, 1991). This multi-regional sector model developed by the Central Planning Bureau focuses on the explanation of regional differences with the national developments of employment by sector of industry. First, for six main sectors of industry an industry-specific model has been estimated on data pooled over provinces and time. For two of these sectors, the manufacturing sector and the service sector, explanatory models are developed, in which region specific unemployment, potential labour supply, investment premiums and population growth (with regard to the service sector) are the most important regressors. Second, these forecasts for six sectors of industry are split up into forecasts for 13 economic sectors by means of a RAS-procedure (see also Bosworth, Evans and Lindley, 1974) starting from actual regional data on employment by economic sector. Next, we differentiate the expected provincial growth in employment by sector into 55 subsectors, on the assumption that all the subsectors belonging to an economic sector undergo the same changes in employment.

In this way the provincial structure by economic subsector is included in the regional occupational model. Provincial changes in employment are then correlated with the actual number of employed in 1989 in the economic subsector in question, so that a forecast of the expected future employment level for each economic subsector in a province can be made.

The national forecasts made by the Central Planning Bureau of the number of persons employed in each economic sector provide the basis for the second step in the regional occupational model, the forecast of the future national expansion demand for each occupational class. This means that our forecasts are consistent with the broadly accepted intermediate and macro-level forecasts of the Central Planning Bureau. These forecasts are based on a multi-sector model of the Dutch economy. For each industrial sector a clay-putty production function with heterogeneous vintages is used. Disequilibrium may arise in the production process and the labour market, which then feeds back into prices, wage rates, investments, the demand for labour, etc. The employment equation for the manufacturing sectors is derived from the model for production capacity and consists of three parts. One part describing the vintage effect on labour volume, one part describing the 'disembodied' changes in the number of jobs and one part describing the short term adaption processes. The employment level equations for the remaining economic sectors are not derived from a formal production function but were formulated ad hoc on the basis of the characteristics of each sector ${ }^{4}$.

By means of the 'national occupational model' the sectoral changes in employment are differentiated by occupational class. In this Modified Multinomial Logit model (see Parks, 1980 and Peeters, 1990), the occupational structure within economic sectors is explained from

4. A more extensive description of this model is given in Dekker, De Grip and Heijke (1992), see also Dekker, De Grip and Heijke (1990). 
developments on the demand side of the labour market: technological change, trade cycle factors and trends. One of the most important factors to be investigated is technological development. Technological development may well cause substitution of occupations within sectors of industry. Note that the effect of technological development on the relative growth in employment in the different sectors has not been considered. Here the analysis only considers changes in the shares of the occupational classes within a given sector. This technology variable is provided by a (structural) capital-labour ratio that represents the capital intensity of production for each sector. The second explanatory factor is the cyclical fluctuation of the occupational structure, measured by the degree of capital utilisation within a sector. Employment in some occupations can be more sensitive to the business cycle than others (e.g. 'overhead' occupations). Moreover cyclical effects could be the motive for hiring workers of some occupations or dismissing others at a faster rate then before. Relative wage costs are not included in the model because of the lack of adequate data. Consequently, we assume that the wage structure as such does not change, or that the influence of the wage structure on the occupational structure of employment within economic sectors is constant. By combining the predicted changes in future employment levels with the actual numbers of employed for each economic subsector and occupational class in 1989, a forecast is obtained of the future growth in the numbers employed for each economic subsector and occupational class. It is assumed that the relative changes for an occupational class will be the same in all economic subsectors within a given industrial sector.

Next the results of the two steps explained above are combined, in order to obtain the changes in employment in each province for each occupational class. For this, the expected employment shares of the occupational classes in the economic subsectors are determined for the years 1989 and 1994, assuming that the occupational class structure within economic subsectors is the same in all provinces. This assumption is consistent with the observation that in reality there are only few regional differences in the occupational class structure within economic sectors (see Berendsen, De Grip, Wieling and Willems, 1992). On the basis of these shares and the numbers employed in each economic subsector in a province, the expected numbers of workers in each occupational class in a province can be determined for both 1989 and 1994 thus giving a forecast of the expected relative growth or decrease in employment in the province for each occupational class for the period 1989-1994. The final result is represented in figure 2 by the upper shaded rectangle. The expected changes in absolute provincial employment levels for each occupational class can subsequently be obtained by projecting the expected relative development onto the actual numbers for employment in each occupational class and province.

The results from the regional occupational model obtained above are the starting point of the forecasts of the future provincial expansion demand by type of education. Moreover the national forecasts relating to the expected numbers employed in each occupational class and by 
type of education for the years $1989^{5}$ and 1994 are used. The expected expansion demand by type of education for the period 1989-1994 is determined by means of the 'national educational model'. This Modified Multinomial Logit model analyzes the changes in the educational structure within occupations on the basis of economic factors and possible trends. The premise of the model is that demand as well as supply factors can have an influence on the educational structure of the various occupations. Technological changes, which explain any rise or fall in the level of education required to practice a certain occupation, are implicitly included in the model. Apart from that, the demand for persons with a given qualification can also be influenced by the relative shortage of workers with that educational background. Through an adjustment in wages or crowding out mechanisms the supply of workers with a certain education can therefore have an influence on the demand for the educational category concerned $^{6}$. The final effect of technological progress on the skill structure (whether upgrading or downgrading effects prevail) can not be assessed unequivocally in advance, as is shown by Spenner (1985). Therefore we include technological progress, again provided by the structural capital-labour ratio, in the educational model, without making a priori statements about its expected results.

As has been said before the skill structure of occupations can also be influenced by a labour supply 'push' effect. Especially in the sense the more highly qualified workers displace the less skilled from their 'occupational territory'. This crowding-out process (Teulings and Koopmanschap, 1989) is a typical one-way process. However the neo-classical substitution concept also recognises the possibility of the less educated replacing the more highly skilled due to a shift in relative wages. In this context the proportion of workers with a given educational level in the potential labour force can be considered as a proxy for these relative wages. This displacement variable we use as a regressor in our educational model can therefore be interpreted in a more general sense as a variable modelling skill substitution processes set in motion by supply factors.

In order to obtain the expected future changes in provincial employment for each type of education, the regional educational model combines the results of the regional occupational model with those of the national educational model. To do this, the share of the types of education in the employment available in each occupational class is determined for the years 1989 and 1994, on the basis of the forecasting model mentioned above. This is done on the assumption that the educational structure of employment for each occupational class in the various provinces does not differ from the national picture. This assumption can also be said to be plausible, since only slight regional differences in educational structure have actually been observed within the occupational classes as defined here (see Berendsen, De Grip, Wieling and

5. Since no actual educational data is available for 1989 , the implicit forecast of the educational structure of employment within occupational classes was taken for this year.

6. More details of this model are given in Dekker, De Grip and Heijke (1992), see also Beekman, Dekker, De Grip and Heijke (1991). 
Willems, 1992). With the aid of this division of the employment for each occupational class into the shares of each type of education, and the forecast of the numbers employed in each occupational class in each province, we can obtain forecasts of the expected relative provincial growth or decline in employment by type of education for the period 1989-1994. This final result for each type of education is represented by the lower shaded rectangle. Moreover, the expected relative changes can be projected onto the actual data of the number of employed for each type of education in the various provinces to give the absolute employment growth for each type of education.

\section{Forecasting results for the expansion demand by occupational class}

In table 1 the results of the regional occupational model for five of the 93 occupational classes are presented, in order to give a picture of the available provincial labour market forecasts. In the table the expansion demand is expressed as a percentage of the numbers employed in 1989. If the number employed in an occupational class in a province is less than 5,000 , no employment forecasts are presented.

Table 1. Expansion demand by occupational class and province 1989-1994, in percentages of employment in 1989

code occupational classes

Province

2011

3721

6124

6211

8211 Total

\begin{tabular}{|c|c|c|c|c|c|c|}
\hline & $\%$ & $\%$ & $\%$ & $\%$ & $\%$ & $\%$ \\
\hline Groningen & -18 & - & -1 & 21 & 16 & 5 \\
\hline Friesland & -16 & - & 1 & 23 & 20 & 6 \\
\hline Drenthe & -16 & - & 2 & 23 & 19 & 6 \\
\hline Overijssel & -17 & 6 & 3 & 24 & 21 & 7 \\
\hline Gelderland & -13 & 6 & 2 & 23 & 20 & 6 \\
\hline Utrecht & -14 & 9 & 3 & 26 & 23 & 11 \\
\hline North Holland & -14 & 6 & -1 & 21 & 19 & 7 \\
\hline South Holland & -11 & 5 & -1 & 20 & 17 & 5 \\
\hline Zeeland & - & - & 1 & 21 & 20 & 6 \\
\hline North Brabant & -15 & 4 & 2 & 23 & 20 & 6 \\
\hline Limburg & -15 & 3 & 1 & 22 & 21 & 6 \\
\hline Flevoland & -12 & - & - & 31 & - & 11 \\
\hline Total & -14 & 5 & 1 & 22 & 19 & 7 \\
\hline \multicolumn{7}{|l|}{$-=$ unknown } \\
\hline \multicolumn{7}{|c|}{$\begin{array}{l}2011 \text { Agricultural and forestry workers } \\
3721 \text { Electricians and electrical and telecommunication servicemen } \\
6124 \text { Book-keepers, cashiers and bank and tax department employees } \\
6211 \text { Sales assistants and demonstrators } \\
8211 \text { Porters, cleaners, domestics, etc. }\end{array}$} \\
\hline
\end{tabular}

Source: ROA 
Employment in the Netherlands is expected to grow in the period 1989-1994 by over 400,000 persons, which is $7 \%$ of the total number employed in 1989. A growth in employment is expected for all provinces over this period. It is notable that the relative growth in employment for Utrecht and Flevoland is expected to be higher than the national expansion demand. The provinces of Groningen and South Holland lag somewhat behind the expected national employment growth.

In accordance with the expected changes in national employment for 'Agricultural and forestry workers', employment for this occupational class is expected to decrease in all provinces in the period 1989-1994. The decrease in the provinces of Groningen and Overijssel in particular is relatively large. The employment decline is, in percentage terms, smallest in the province of South Holland. The occupational class 'Electricians and electrical and telecommunication servicemen' is characterized by an expected high relative employment growth in particular in the province of Utrecht. For the occupational class 'Book-keepers, cashiers and bank and tax department employees', a small increase is expected in national employment but a slight employment decline is expected in the provinces of Groningen, North Holland and South Holland. The great relative increase in national employment for 'Sales assistants and demonstrators' and 'Porters, cleaners, domestics, etc.' can also be found for all separate provinces. As regards the 'Sales assistants and demonstrators', it is striking that the expected expansion demand for the provinces of Flevoland and Utrecht is relatively high. The province of Groningen shows a relatively low employment growth for the occupational class 'Porters, cleaners, domestics, etc.', whereas the expansion demand for this group is expected to be relatively high in the province of Utrecht.

\section{Forecasting results of the expansion demand for by type of education}

Table 2 gives the forecasting results of the expansion demand for four types of education. Employment for workers with 'Lower General Secondary Education' will go up in practically all provinces. For the province of South Holland a small fall in employment is expected. On the other hand, the expansion demand for this type of education for the province of Flevoland is expected to be relatively high. For 'Lower Vocational Education, Technical' the expected national decline in employment in the period 1989-1994 is reflected in all provinces, but a smaller decline of employment is expected for the provinces of Utrecht and Flevoland. The two types of education at Intermediate Vocational level show a favourable development in employment, which is reflected in all provinces. The employment growth in percentage terms for 'Intermediate Vocational Education, Technical' and 'Intermediate Vocational Education, Commerce \& Administration' is highest in the provinces of Utrecht and Flevoland. 
$-11-$

Table 2. Expansion demand by type of education and province 1989-1994, in percentages of employment in 1989

\begin{tabular}{|c|c|c|c|c|}
\hline Province & $\begin{array}{l}\text { Lower General } \\
\text { Secondary } \\
\text { Education }\end{array}$ & $\begin{array}{l}\text { L.V.E. } \\
\text { Technical }\end{array}$ & $\begin{array}{l}\text { I.V.E. } \\
\text { Technical }\end{array}$ & $\begin{array}{c}\text { I.V.E. } \\
\text { Commerce \& } \\
\text { Administration }\end{array}$ \\
\hline
\end{tabular}

\begin{tabular}{lcccc}
\hline & $\%$ & $\%$ & $\%$ & $\%$ \\
Groningen & 2 & -5 & 8 & 16 \\
Friesland & 4 & -6 & 8 & 18 \\
Drenthe & 3 & -7 & 7 & 17 \\
Overijssel & 5 & -6 & 8 & 19 \\
Gelderland & 3 & -7 & 7 & 17 \\
Utrecht & 5 & -2 & 11 & 21 \\
North Holland & 1 & -6 & 7 & 16 \\
South Holland & -0 & -7 & 6 & 15 \\
Zeeland & 2 & -8 & 6 & 17 \\
North Brabant & 3 & -7 & 7 & 17 \\
Limburg & 3 & -2 & 11 & 23 \\
Flevoland & 7 & -6 & 7 & 17 \\
Total & 2 & & & \\
L.V.E. Lower Vocational Education & & & \\
l.V.E. Intermediate Vocational Education & & & \\
\end{tabular}

Source: ROA 


\section{REPLACEMENT DEMAND}

\section{Methodology}

Apart from the expected expansion demand, the future replacement demand is also important in determining the total demand for newcomers on the labour market. This replacement demand can be the result of retirement, the early retirement scheme, temporary or final exit from the labour market by married women, in particular for the care of children, and occupational mobility (see Willems and De Grip, 1992). The national replacement demand forecast for each occupational class is determined by 'extrapolating' the sex and age specific net cohort-change rates (see also Shryock and Siegel, 1980) for each occupational class, observed in the analysis period 1981-1985, into the future. This projection incorporates a correction for trade cycle effects in the analysis period, and another for future changes in the participation rate (for further details see Willems and De Grip, 1992). The national forecast of the replacement demand by type of education is obtained in a similar way, but with one important difference. In contrast to the replacement demand by occupational class, occupational mobility does not influence the replacement demand by type of education. Because of this the average replacement demand for the various types of education is lower than the average replacement demand for the occupational classes.

Using this methodology the future replacement demand by provinces by occupational class and by type of education can then be determined as well. Just as in the expansion demand forecast, we chose not to make a specific analysis at provincial level of the historical developments. Instead, the expected national turnover ratios (by sex and age category) are projected onto the sex and age structure of provincial employment. In view of the often inadequate cell filling of the data regarding the number of employed in a province by occupational class or type of education broken down by sex and age categories, this method is preferable to determining the turnover ratios at provincial level. Moreover the turnover ratios for sex and age categories would be expected to differ little between provinces. The possible differences in the sex and age structure of employment between provinces, which are taken into account, are much more important. This method also ensures that the sum of the replacement demand over the provinces is consistent with the national total.

\section{Forecasting results of the replacement demand by occupational class}

The results of the provincial replacement demand for each occupational class in the period 1989-1994 have been represented in table 3. From a national point of view the average replacement demand for all occupational classes is $12 \%$ of the numbers employed in 1989 , or about 715,000 workers. The total replacement demand percentage differs little between the various provinces, except that the 'new' province of Flevoland has a somewhat lower rate. This is obviously related to the relatively young average age of the workforce in this province. 
Table 3. Replacement demand by occupational class and province 1989-1994, in percentages of employment in 1989

\begin{tabular}{|c|c|c|c|c|c|c|}
\hline \multirow[b]{2}{*}{ Province } & \multicolumn{3}{|c|}{ code occupational classes } & \multirow[b]{2}{*}{6211} & \multirow[b]{2}{*}{8211} & \multirow[b]{2}{*}{ Total } \\
\hline & 2011 & 3721 & 6124 & & & \\
\hline & $\%$ & $\%$ & $\%$ & $\%$ & $\%$ & $\%$ \\
\hline Groningen & 18 & - & 10 & 18 & 14 & 12 \\
\hline Friesland & 9 & - & 10 & 18 & 12 & 11 \\
\hline Drenthe & 16 & - & 11 & 14 & 16 & 12 \\
\hline Overijssel & 19 & 15 & 9 & 19 & 13 & 12 \\
\hline Gelderland & 16 & 11 & 9 & 17 & 11 & 11 \\
\hline Utrecht & 14 & 7 & 10 & 21 & 11 & 12 \\
\hline North Holland & 11 & 13 & 10 & 18 & 12 & 12 \\
\hline South Holland & 14 & 13 & 8 & 18 & 13 & 12 \\
\hline Zeeland & - & - & 6 & 19 & 12 & 12 \\
\hline North Brabant & 14 & 11 & 9 & 18 & 12 & 11 \\
\hline Limburg & 11 & 11 & 8 & 20 & 11 & 12 \\
\hline Flevoland & 13 & - & - & 19 & - & 10 \\
\hline Total & 14 & 12 & 9 & 18 & 12 & 12 \\
\hline \multicolumn{7}{|l|}{$-=$ unknown } \\
\hline \multicolumn{7}{|c|}{$\begin{array}{l}2011 \text { Agricultural and forestry workers } \\
3721 \text { Electricians and electrical and telecommunication servicemen } \\
6124 \text { Book-keepers, cashiers and bank and tax department employees } \\
6211 \text { Sales assistants and demonstrators }\end{array}$} \\
\hline
\end{tabular}

Source: ROA

The occupational classes presented in table 3 show a more differentiated picture. The expected replacement demand for 'Agricultural and forestry workers' is relatively low for the provinces of Friesland, North Holland and Limburg. In the provinces of Groningen and Overijssel, on the other hand, there is a relatively high replacement demand compared to the national forecast. For Overijssel the replacement demand for 'Electricians and electrical and telecommunication servicemen' is also expected to be relatively high. The expected replacement demand for this occupational class is relatively low in the province of Utrecht.

The province of Zeeland will have by expectation a relatively low replacement demand for 'Book-keepers, cashiers, and bank and tax department employees', while in the province of Drenthe the replacement demand will be somewhat higher than the national forecast. It is expected that the future replacement demand for 'Sales assistants and demonstrators' will vary from $14 \%$ in Drenthe to $21 \%$ in the province of Utrecht. Finally, the relatively high replacement demand for 'Porters, cleaners, domestics, etc.' in the province of Drenthe is especially notable, while the province of Groningen also shows a rate somewhat higher than the national figure for this occupational class. 
Table 4 gives a picture of the expected provincial replacement demand in the period 1989-1994 for the four types of education for which the expansion demand has also been presented. The variation in the replacement demand between the provinces is very small for these four types of education. In the province of Overijssel the replacement demand for those with 'Lower General Secondary Education' is relatively low compared to the national average for this type of education, whereas in the province of Zeeland it is higher than the national average. For 'Lower Vocational Education, Technical' it is especially notable that replacement demand in Friesland and Zeeland is expected to be relatively low. The expected replacement demand percentages for 'Intermediate Vocational Education, Technical' in the various provinces differ only slightly from the national average. In the province of Groningen there is a relatively high replacement demand for 'Intermediate Vocational Education, Commerce \& Administration', while in Flevoland a relatively low replacement demand is expected for this type of education.

Table 4. Replacement demand by type of education and province 1989-1994, in percentages of employment in 1989

\begin{tabular}{|c|c|c|c|c|}
\hline Province & $\begin{array}{c}\text { Lower General } \\
\text { Secondary } \\
\text { Education }\end{array}$ & $\begin{array}{l}\text { L.V.E. } \\
\text { Technical }\end{array}$ & $\begin{array}{l}\text { I.V.E. } \\
\text { Technical }\end{array}$ & $\begin{array}{c}\text { I.V.E. } \\
\text { Commerce \& } \\
\text { Administration }\end{array}$ \\
\hline & $\%$ & $\%$ & $\%$ & $\%$ \\
\hline Groningen & 15 & 14 & 6 & 11 \\
\hline Friesland & 15 & 13 & 6 & 9 \\
\hline Drenthe & 14 & 14 & 5 & 6 \\
\hline Overijssel & 12 & 15 & 6 & 6 \\
\hline Gelderland & 15 & 15 & 7 & 8 \\
\hline Utrecht & 14 & 18 & 7 & 9 \\
\hline North Holland & 14 & 17 & 7 & 9 \\
\hline South Holland & 15 & 17 & 7 & 8 \\
\hline Zeeland & 16 & 13 & 6 & 7 \\
\hline North Brabant & 14 & 16 & 6 & 6 \\
\hline Limburg & 14 & 15 & 6 & 6 \\
\hline Flevoland & 13 & 14 & 5 & 5 \\
\hline Total & 14 & 16 & 6 & 8 \\
\hline \multicolumn{5}{|c|}{$\begin{array}{ll}\text { L.V.E. } & \text { Lower Vocational Education } \\
\text { I.V.E. } & \text { Intermediate Vocational Education }\end{array}$} \\
\hline
\end{tabular}

Source: ROA 


\section{JOB OPENINGS}

\section{Forecasting results of job openings by occupational class}

The expected total demand for newcomers (the number of 'job openings') on the labour market is obtained by combining the provincial forecasts of employment growth with the provincial replacement demand forecasts. In table 5 the future job openings for the five selected occupational classes in the various provinces are presented.

Table 5. Job openings by occupational class and province 1989-1994, in percentages of employment in 1989

\begin{tabular}{|c|c|c|c|c|c|c|}
\hline \multirow[b]{2}{*}{ Provincie } & \multicolumn{3}{|c|}{ code occupational classes } & \multirow[b]{2}{*}{6211} & \multirow[b]{2}{*}{8211} & \multirow[b]{2}{*}{ Total } \\
\hline & 2011 & 3721 & 6124 & & & \\
\hline & $\%$ & $\%$ & $\%$ & $\%$ & $\%$ & $\%$ \\
\hline Groningen & 18 & - & 10 & 38 & 30 & 17 \\
\hline Friesland & 9 & - & 12 & 41 & 32 & 17 \\
\hline Drenthe & 16 & - & 13 & 37 & 35 & 17 \\
\hline Overijssel & 19 & 22 & 11 & 43 & 34 & 19 \\
\hline Gelderland & 16 & 17 & 11 & 40 & 31 & 18 \\
\hline Utrecht & 14 & 16 & 13 & 46 & 34 & 23 \\
\hline North Holland & 11 & 19 & 10 & 39 & 31 & 19 \\
\hline South Holland & 14 & 17 & 8 & 38 & 30 & 17 \\
\hline Zeeland & - & - & 7 & 41 & 32 & 17 \\
\hline North Brabant & 14 & 15 & 10 & 41 & 32 & 17 \\
\hline Limburg & 11 & 14 & 9 & 42 & 31 & 18 \\
\hline Flevoland & 13 & - & - & 50 & - & 20 \\
\hline Total & 14 & 17 & 10 & 40 & 32 & 18 \\
\hline \multicolumn{7}{|l|}{$-=$ unknown } \\
\hline \multicolumn{7}{|c|}{$\begin{array}{l}2011 \text { Agricultural and forestry workers } \\
3721 \text { Electricians and electrical and telecommunication servicemen } \\
6124 \text { Book-keepers, cashiers and bank and tax department employees } \\
6211 \text { Sales assistants and demonstrators } \\
8211 \text { Porters, cleaners, domestics, etc. }\end{array}$} \\
\hline
\end{tabular}

Source: ROA

The total number of job openings in the Netherlands in the period 1989-1994 is expected to be over 1.1 million. This is $18 \%$ of the total numbers employed in 1989. The largest number of job openings, in percentage terms, in this period are expected for the provinces of Utrecht and Flevoland, which is due to their relatively high expansion demand as compared to the national rate. In the other provinces the total expected demand for newcomers coincides more or less with the total percentage for job openings in the Netherlands. 
$-16-$

For 'Agricultural and forestry workers' in all provinces, the total demand for newcomers consists solely of the future replacement demand. For 'Electricians and electrical and telecommunication servicemen' it can be seen that the expected total future demand is relatively high in the province of Overijssel. This is related to the relatively high replacement demand for this occupational class in that province. In North Brabant and Limburg on the other hand there is a relatively low expected total demand. Comparatively many job openings for 'book-keepers, cashiers, and bank and tax department employees' are expected in the provinces of Drenthe and Utrecht. This is especially due to a relatively high replacement demand, although for the province of Utrecht there is also a relatively high employment growth. In the province of Zeeland the total demand for newcomers in the period 1989-1994 is expected to lag somewhat behind the national demand for newcomers. This has to do with a relatively low replacement demand forecast.

In contrast to the situation for the three occupational classes mentioned above, the expected expansion demand makes up an important part of the total demand for newcomers in the other two selected occupational classes. In line with its relatively low replacement demand, the province of Drenthe shows comparatively the fewest expected job openings for 'Sales assistants and demonstrators'. For this occupational class the total demand for newcomers in the provinces of Utrecht and Flevoland is higher than the national demand, which has to do with the relatively high employment growth in these provinces already mentioned above. Compared to the total national demand for newcomers, the occupational class 'Porters, cleaners, domestics, etc.' is characterized by a high number of job openings in the province of Drenthe. This is caused by the relatively high replacement demand for this occupational class in that province.

\section{Forecasting results of job openings by type of education}

In general it can be seen that, in all provinces, the replacement demand plays an important role in the total demand for newcomers from 'Lower General Secondary Education' and 'Lower Vocational Education, Technical'. For the latter type of education the total demand is in fact completely determined by the replacement demand, due to the negative employment growth in all provinces. The same applies for 'Lower General Secondary Education' in the province of South Holland. Compared to the expected national number of job openings for those with 'Lower General Secondary Education', the province of Flevoland is characterized by a relatively higher expected demand for newcomers. This is caused by the relatively high expansion demand, as compared to national changes in employment.

The job openings for 'Intermediate Vocational Education, Technical' and 'Intermediate Vocational Education, Commerce \& Administration' consist predominantly of the expected employment growth in the period 1989-1994. The relatively high employment growth rates for 'Intermediate Vocational Education, Technical' and 'Intermediate Vocational Education, Commerce \& Administration' in the provinces of Utrecht and Flevoland are clearly reflected in the expected total demand for newcomers. 
$-17-$

Table 6. Job openings by type of education and province 1989-1994, in percentages of employment in 1989

\begin{tabular}{|c|c|c|c|c|}
\hline Province & $\begin{array}{l}\text { Lower General } \\
\text { Secondary } \\
\text { Education }\end{array}$ & $\begin{array}{l}\text { L.V.E. } \\
\text { Technical }\end{array}$ & $\begin{array}{l}\text { I.V.E. } \\
\text { Technical }\end{array}$ & $\begin{array}{c}\text { I.V.E. } \\
\text { Commerce \& } \\
\text { Administration }\end{array}$ \\
\hline
\end{tabular}

\begin{tabular}{lcccc}
\hline & $\%$ & $\%$ & $\%$ & $\%$ \\
Groningen & 16 & 14 & 13 & 27 \\
Friesland & 19 & 13 & 14 & 27 \\
Drenthe & 17 & 14 & 11 & 23 \\
Overijssel & 17 & 15 & 14 & 25 \\
Gelderland & 18 & 15 & 14 & 25 \\
Utrecht & 19 & 18 & 18 & 29 \\
North Holland & 15 & 17 & 14 & 25 \\
South Holland & 15 & 17 & 13 & 23 \\
Zeeland & 18 & 13 & 12 & 24 \\
North Brabant & 17 & 16 & 12 & 24 \\
Limburg & 17 & 15 & 13 & 28 \\
Flevoland & 20 & 14 & 16 & \\
Total & 17 & 16 & 13 & \\
& & & & \\
L.V.E. Lower Vocational Education & & & \\
l.V.E. Intermediate Vocational Education & & & \\
&
\end{tabular}

Source: ROA 


\section{INFLOW OF SCHOOL LEAVERS}

\section{Methodology}

There are no explanatory models underlying the methodology used in estimating the provincial flows of school leavers onto the labour market. The method can be split into two steps. In the first step forecasts of the provincial flow of pupils from regular full-time education are drawn up, by type of education. In the second step a correction is made to these forecasts in order to account for the flow from regular full-time education to non-regular full-time education and regular or non-regular part-time education, and for the qualifications obtained in this way. More details of the methodology can be found in Berendsen, De Grip, Wieling and Willems (1992).

The starting point for the provincial forecasts of the future flow of school leavers from each type of education onto the labour market is a regional forecast of the future flow from secondary education, classified by school type and whether or not a diploma is awarded (Vermeulen, 1990). In this model, that is based on the national SKILL forecasting model of the Ministry of Education and Science (1990), flow coefficients relate the 'origin' of students in year $t$ to the 'destination' of these students in year $t+1$. The expected number of qualified school leavers for each school type follows directly from these forecasts. The school leavers without a diploma should however first be attributed to the school type of any earlier education which they did conclude by obtaining a diploma (see also Berendsen, Dekker, De Grip and Van de Loo, 1992). This is done by ascertaining, on the basis of the national educational matrix of the NCBS, the distribution of the schools of origin of the flow into each type of secondary education (type of school of destination) in the school year 1989/1990.

There are however also school leavers who leave higher education without obtaining a diploma. These drop-outs should also be included in the forecasts, in so far as their highest completed preliminary education is one of the types of education for which provincial forecasts are made. For this purpose the expected numbers of drop-outs from higher education, from the national SKILL education forecast of the Ministry of Education and Science (1990), are taken as a basis. The required provincial forecasts of the number of school leavers from regular full-time education are obtained by combining the forecasts mentioned above.

However school leavers from regular full-time education often go on to non-regular full-time education and regular and non-regular part-time education, including various forms of vocationally oriented adult education. These flows are taken into account in the second step of the estimation methodology. For lack of adequate regional data we assume that for each type of education the provincial flow coefficients equal the corresponding national flow coefficient. This coefficient is multiplied by the actual number of school leavers of the types of education in various provinces. However, Shorter Intermediate Vocational Education and the Apprenticeship System are left out in this procedure, because the data available enables to draw up separate provincial forecasts for these. By combining these forecasts with those for part-time education and non-regular full-time education on the one hand with the forecasts for school leavers from 
full-time education (final result of step 1 ) on the other hand, the required final result is obtained: provincial forecasts of the flow of school leavers onto the labour market, for each type of education, in the period 1989-1994.

\section{Forecasting results of the inflow of school leavers by type of education}

In table 7 an overview is given of the expected flow of school leavers onto the labour market in the period 1989-1994, for four types of education. The expected percentage flows of school leavers from 'Lower General Secondary Education' show only slight differences between the provinces. For 'Lower Vocational Education, Technical' the expected provincial flow percentages also fall within a rather limited range, with the province of Overijssel in particular expected to have flows below the national figure, while North Holland is expected to have relatively high flows.

Table 7. Inflow of school leavers by type of education and province 1989-1994, in percentages of employment in 1989

\begin{tabular}{lcccc}
\hline Province & $\begin{array}{c}\text { Lower General } \\
\text { Secondary } \\
\text { Education }\end{array}$ & $\begin{array}{c}\text { L.V.E. } \\
\text { Technical }\end{array}$ & $\begin{array}{c}\text { I.V.E. } \\
\text { Technical }\end{array}$ & $\begin{array}{c}\text { I.V.E. } \\
\text { Commerce \& } \\
\text { Administration }\end{array}$ \\
\hline & $\%$ & $\%$ & $\%$ & $\%$ \\
Groningen & 8 & 14 & 26 & 21 \\
Friesland & 10 & 15 & 20 & 25 \\
Drenthe & 10 & 12 & 28 & 26 \\
Overijssel & 8 & 9 & 29 & 27 \\
Gelderland & 8 & 12 & 20 & 15 \\
Utrecht & 6 & 13 & 22 & 15 \\
North Holland & 7 & 16 & 22 & 20 \\
South Holland & 8 & 12 & 24 & 20 \\
Zeeland & 6 & 14 & 29 & 22 \\
North Brabant & 8 & 13 & 21 & 18 \\
Limburg & 9 & 12 & 18 & 19 \\
Flevoland & 6 & 11 & 27 & \\
Total & 8 & 13 & 23 & \\
& & & & \\
L.V.E. Lower Vocational Education & & & \\
I.V.E. Intermediate Vocational Education & & & & \\
\hline
\end{tabular}

Source: ROA

For 'Intermediate Vocational Education, Technical' and 'Intermediate Vocational Education, Commerce \& Administration', somewhat larger differences between the expected provincial labour market flows are expected. As compared with the national picture, 'Intermediate Vocational Education, Technical' shows an especially low flow of school leavers onto the labour market for the province of Limburg, and relatively high flows in the provinces of Drenthe, 
Overijssel and Zeeland in particular. For 'Intermediate Vocational Education, Commerce \& Administration' it is especially the provinces of Utrecht and North Holland which can expect low flows of school leavers onto the labour market, as compared to the national percentage. The provinces of Friesland, Drenthe and Overijssel on the other hand are characterized by relatively high future inflows. 


\section{CHARACTERIZATION OF THE FUTURE LABOUR MARKET SITUATION}

In this section an indication will be given of the expected future labour market situation for each type of education. This will be done by means of an indicator of the future labour market situation (IFL). A confrontation is made between the expansion and replacement demand and, on the other hand, the expected flow of school leavers onto the labour market and the supply of workers who were unemployed at the beginning of the forecasting period. As for this last group, only those unemployed for less than one year are taken into account, assuming that those who have been unemployed for longer than one year hardly compete with school leavers with the same educational background. If the indicator of the future labour market situation has the value 1 , this means that the demand and supply are expected to be in balance. Qualitative descriptions are given of the expected labour market situation of each type of education, based on the division below (for a more detailed explanation see Dekker, De Grip and Heijke, 1992).

$\mathrm{IFL} \leq 1.00$ good labour market prospects

$1.00<\mathrm{IFL} \leq 1.05$ reasonable labour market prospects

$1.05<\mathrm{IFL} \leq 1.10$ moderate labour market prospects

$1.10<\mathrm{IFL} \quad$ poor labour market prospects

As has been noted earlier, in categorizing the provincial labour market situation by type of education possible inter-regional mobility flows are not taken into account. The forecasting results therefore in fact give an indication of the regional differences in the expected labour market position and the direction of the mobility flows required to smooth out the regional differences. For this reason the provincial indicators of the future labour market situation are only discussed in comparison with the national indicator for that type of education.

Table 8 shows that the future labour market situation for 'Lower General Secondary Education' lies on the border between 'good' and 'reasonable'. The good labour market prospects expected at national level can be found in practically all provinces, except the provinces of Groningen, Friesland and North Holland, where the future labour market situation is expected to be somewhat less favourable. For 'Lower Vocational Education, Technical', for which the expected labour market situation is at national level characterized as 'moderate', the provinces show a wider range of characterizations. It is especially striking that the three northern provinces (Groningen, Friesland and Drenthe) and Zeeland are characterized by poor labour market prospects. On the other hand, the labour market prospects for the province of Utrecht in particular are expected to be much more favourable, which is mainly caused by the less unfavourable movement which is expected in the employment levels for this province. For the provinces of Overijssel and Flevoland the labour market expectations for this type of education are also relatively favourable as compared to the national expectations.

For 'Intermediate Vocational Education, Technical' there are also significant differences between the characterizations of the future labour market situation in the provinces. In the provinces of Groningen, Drenthe, Overijssel and Zeeland the labour market prospects are clearly 
worse than the national prospects for this type of education. The provinces of Utrecht and Limburg, in contrast, show a more favourable picture than the national expectations for this type of education. In accordance with the national expectations of the future labour market situation for those with 'Intermediate Vocational Education, Commerce \& Administration', good labour market prospects are expected for practically all provinces. Exceptions are the provinces of Drenthe and Overijssel, where the labour market prospects are expected to be less favourable. For the province of Drenthe this is caused by a relatively low replacement demand, whereas for the province of Overijssel the less favourable labour market prospects are the result of the expected high flow of school leavers. For the provinces of Utrecht, Flevoland and North Holland, in particular, a tight labour market is expected for this type of education.

Table 8. Future labour market situation by type of education and province 1989-1994

\begin{tabular}{|c|c|c|c|c|}
\hline Province & $\begin{array}{l}\text { Lower General } \\
\text { Secondary } \\
\text { Education }\end{array}$ & $\begin{array}{l}\text { L.V.E. } \\
\text { Technical }\end{array}$ & $\begin{array}{l}\text { I.V.E. } \\
\text { Technical }\end{array}$ & $\begin{array}{c}\text { I.V.E. } \\
\text { Commerce \& } \\
\text { Administration }\end{array}$ \\
\hline Groningen & 1.01 & 1.15 & 1.15 & 0.97 \\
\hline Friesland & 1.01 & 1.18 & 1.07 & 1.00 \\
\hline Drenthe & 0.99 & 1.12 & 1.16 & 1.03 \\
\hline Overijssel & 0.99 & 1.05 & 1.15 & 1.02 \\
\hline Gelderland & 0.97 & 1.08 & 1.07 & 0.97 \\
\hline Utrecht & 0.94 & 1.01 & 1.05 & 0.90 \\
\hline North Holland & 1.02 & 1.11 & 1.08 & 0.93 \\
\hline South Holland & 1.00 & 1.08 & 1.12 & 0.97 \\
\hline Zeeland & 0.95 & 1.14 & 1.16 & 0.98 \\
\hline North Brabant & 0.98 & 1.09 & 1.10 & 0.97 \\
\hline Limburg & 0.99 & 1.10 & 1.06 & 0.99 \\
\hline Flevoland & 0.96 & 1.05 & 1.11 & 0.92 \\
\hline Total & 0.99 & 1.09 & 1.10 & 0.96 \\
\hline $\begin{array}{l}\text { L.V.E. } \\
\text { I.V.E. }\end{array}$ & $\begin{array}{l}\text { tional Education } \\
\text { Vocational Educ }\end{array}$ & & & \\
\hline
\end{tabular}

Source: ROA 


\section{CONCLUSION}

In this paper a methodology has been developed to set up regional labour market forecasts by occupation and education. In this approach national medium-term labour market forecasts are differentiated by province. Forecasts were only drawn up for the occupational classes and types of education with at least 5,000 persons employed in the province. Moreover, Higher Vocational Education and Academic Education, along with 'Intermediate Vocational Education, Police \& Defense Forces', were left out, since the labour markets for these types of education have little or no regional characteristics. In drawing up the regional forecasts an approach was chosen in which the national forecasting results are divided by provinces. The underlying results or interim results from the national forecasting models on the one hand and the results of some existing 'external' provincial forecasting studies and various labour market data by province on the other hand were used for this.

The regional forecasts of expansion demand for each occupational class were created by relating the changes in regional employment in each economic subsector to the expected national changes in employment for each economic subsector and occupational class. In order to obtain the regional forecast of the changes in employment for each type of education, these figures are then combined with the expected national changes in the share of each type of education in each occupational class. Since few regional differences in the distribution of occupational classes over the economic sectors or in the occupational class structure of each type of education can be actually observed, the assumptions required in this process can be said to be plausible.

For the forecast of the regional replacement demand for each occupational class and for each type of education, the expected national cohort-change ratios for each occupational class or type of education and for each sex and age category are related to the provincial sex and age structure of the workforce in the occupational classes and types of education in question. This is done on the plausible assumption that the turnover rates within the separate sex and age groups do not vary between the provinces. This makes it possible to draw up replacement demand forecasts for each of the occupational classes and types of education which we have distinguished. It should however be noted that for small occupational classes and types of education the reliability may be lower, due to the inevitable sample and measurement errors to which the employment figures of the Labour Force Survey may be liable when so highly disaggregated.

The forecasts of the regional flows onto the labour market of school leavers from each type of education are made using many sources of data. The basis is the data on the regional flows from secondary education. Apart from that, data relating to the 'flow-on' to regular and nonregular part-time education and adult education is used. With the exception of the Shorter Intermediate Vocational Education and the Apprenticeship System, these are national flow coefficients. On the basis of this methodology it is possible to draw up provincial forecasts. It is however necessary to make some important assumptions, so that the forecasts must be 
interpreted with some caution.

By matching the expected expansion and replacement demand with the inflow of school leavers and the supply of short-term unemployed, an indication of the future labour market situation for each type of education in the various regions is obtained. It is striking that the usually small provincial differences in the employment structure, when combined with differences in the forecast flow of school leavers onto the labour market, can lead to significant differences in the expected situation on the labour market. However these forecasting results, even more than those on a national level, should be seen as indications and not as point estimates. There is always a trade-off between the reliability of the forecasting results and the degree of detail. For labour market policy and vocational and educational counselling these indicators provide adequate information because the labour market prospectives of occupations and types of education are differentiated sufficiently. Moreover, the regional information satisfies the often expressed demand for information of the various actors in the regional labour market who have no interest in national labour market forecasts.

It is also important to observe that poor labour market prospects do not automatically have to lead to high unemployment. A first reaction to possible imbalances on the labour market might be the acceptance of jobs below the educational level achieved ('overschooling'). In the second place there will in practice be a response, in terms of re-education or additional education for the workforce or the unemployed, to any expected shortages or surpluses on the labour market. In the third place regional differences between demand and supply for a certain type of education can lead to geographical mobility of workers or employers. This mobility will of course occur especially when the labour market prospects for a certain type of education differ strongly from the labour markets in other, neighbouring, regions (see also Berendsen, De Grip, Wieling and Willems, 1992). 


\section{REFERENCES}

Beekman Th., Dekker R., De Grip A. and Heijke H. (1991), An Explanation of the Educational Structure of Occupations, Labour, vol. 5, nr. 3, pp.151-163.

Berendsen H., Dekker R.J.P., De Grip A. and Van de Loo P.J.E. (1992), Prognose arbeidsmarktinstroom van schoolverlaters per opleidingstype, ROA-W-1992/2, Research Centre for Education and the Labour Market, Rijksuniversiteit Limburg, Maastricht.

Berendsen H., De Grip A., Wieling M.H. and Willems E.J.T.A. (1992), Regionale arbeidsmarktinformatie naar opleiding en beroep; een verkenning vanuit het ROA-informatiesysteem onderwijs-arbeidsmarkt, ROA-R-1992/2, Research Centre for Education and the Labour Market, Rijksuniversiteit Limburg, Maastricht.

Bosworth D.L., Evans G.J. and Lindley R.M. (1974), Mechanistic Manpower Models, in Wabe J.S. (Ed), Problems in Manpower Forecasting, Saxon House Lexington Books, Farnborough, pp. 61-84.

Dekker R., De Grip A. and Heijke H. (1990), An Explanation of the Occupational Structure of Sectors of Industry, Labour, vol. 4, nr. 3, pp. 3-31.

Dekker R.J.P., De Grip A. and Heijke J.A.M. (1992), The ROA Information System on Education and the Labour Market: Models and Methods, Paper presented at the Symposium ROA-5, May 8th, Research Centre for Education and the Labour Market, Rijksuniversiteit Limburg, Maastricht.

De Grip A. (1991), Meer licht op de regionale arbeidsmarkt, ROA-R-1991/4, Research Centre for Education and the Labour Market, Rijksuniversiteit Limburg, Maastricht.

Foot D. (1980), Labour Market Analysis with Canadian Macroeconometric Models: A Review, Centre for Industrial Relations, University of Toronto, Toronto.

Lindley R.M. and Wilson R.A. (1991) (Eds.), Review of the Economy and Employment 1991: Regional Assessments, Institute for Employment Research, University of Warwick.

Ministry of Education and Science (1990), SKILL 1990-II, internal paper, Zoetermeer.

Natzijl H.P. and Westra P. (1991), Regionale arbeidsmarkt prognose 1991-1996, OAV-rapport 91-08, Rijswijk.

Parks R.W. (1980), On the Estimation of Multinomial Logit Models from Relative Frequency Data, Journal of Economics, vol. 13, pp. 293-303. 
Peeters H.M.M. (1990), An Explanation of the Occupational Structure of Employment by Means of Multinomial Logit, ROA-W-1990/4E, Research Centre for Education and the Labour Market, Rijksuniversiteit Limburg, Maastricht.

Research Centre for Education and the Labour Market (1992), De arbeidsmarkt naar opleiding en beroep tot 1994, ROA-R-1992/1, Research Centre for Education and the Labour Market, Rijksuniversiteit Limburg, Maastricht.

Shryock H.S. and Siegel J.S. (1980), The Methods and Materials of Demography, U.S. Bureau of the Census, U.S. Government Printing Office, Fourth Printing (rev.), Washington, D.C.

Spenner K. (1985), The Upgrading and Downgrading of Occupations, Review of Education Research, vol. 55, pp. 125-154.

Teulings C. and Koopmanschap M. (1989), An Econometric Model of Crowding Out of Lower Education Levels, European Economic Review, vol. 33, pp. 1653-1664.

Vermeulen M. (1990), Regionalisering uitstroom voortgezet onderwijs (RUVO), INRO-TNO, Delft.

Willems E.J.T.A. and De Grip A., (1992), Forecasting Replacement Demand by Occupation and Education, International Journal of Forecasting, (forthcoming). 